Article

\title{
The Italian University Habilitation and the Challenge of Increasing the Representation of Women in Academia
}

\section{Marco Pautasso $1,2, *$}

1 Forest Pathology and Dendrology, Institute of Integrative Biology, ETH Zurich 8092, Switzerland; E-Mail: marpauta@gmail.com; Tel.: +39-0521-036-775

2 Animal and Plant Health Unit, European Food Safety Authority (EFSA), Parma 43126, Italy

* The positions and opinions presented in this article are those of the authors alone and are not intended to represent the views or scientific works of EFSA.

Academic Editor: Andreas Manz

Received: 19 December 2014 / Accepted: 4 March 2015 / Published: 10 March 2015

\begin{abstract}
Increasing the representation of women in academia is a priority challenge in higher education policy. This study uses data from the Italian University habilitation competition in 2012 to test whether this national, standardized and quantitative assessment of researchers contributed to improving the situation. The proportion of female applications (on the whole about 36\%) was in many fields higher than the reported proportion of female University professors $(27 \%, 2010)$, but lower than the proportion of female researchers (2010) in Italy (45\% and 51\% for researchers with and without a permanent position, respectively). There was still a gap between the proportion of female applications at the associate (on average 39\%) and full professor level (29\%). A similar gap was also present between scientific disciplines and the humanities. Average success rates of female applications (41.2\%) were on the whole lower than those of male applications (43.9\%), but in most fields these differences were not significant. Overall, it is generally much lower proportion of female applications rather than their lower success rate that perpetuates the low proportion of female academics in Italy. More effort is needed to support female researchers in choosing and pursuing an academic career.
\end{abstract}

Keywords: academic researchers; career progress; equal opportunities; gender equality; higher education; Italy; research policy; tenure; Universities; women in science 


\section{Introduction}

The underrepresentation of women in academia is a shameful legacy of decades of bias and unequal opportunities [1-3]. Surveys from various countries show that the proportion of female undergraduate and graduate students has been the majority in many fields for many years now, but female senior researchers and professors are still often a small minority [4-6]. Various reasons have been suggested to be responsible for the persistence of a low representation of senior women in academia, e.g., the precarious employment conditions of most early-career researchers, recent University funding cuts, the lack of female role models in senior academic positions, as well as gender bias in (1) editorial boards of journals, (2) invited speakers at conferences, and (3) committees evaluating grant applications, hiring decisions and promotions [7-12].

Recruitment processes have an important influence on the representation of women in academia [13], but they have been less studied than the proportion of female academics having already obtained a permanent position [14]. Nonetheless, a relative reluctance of women academics to apply for promotion is well documented in research across a number of European countries. Much research has been performed on the relationships between gender, organizational cultures and careers in higher education [15-18], but there is the need to further study this issue so as to document, assess and disseminate recent trends. The 2012, University habilitation competition in Italy provides an opportunity to test whether the proportion of female candidates is increasing compared to data reported in the literature. This habilitation is a national competition that, if passed successfully, gives the right to apply to University associate and full professor positions, when these become available at individual Italian Universities. Given that female researchers in Italy have been reported to have had in the past on average $66 \%$ (and no more than $80 \%$ ) of the chances of male researchers to move from a researcher to a professor position [19], the adoption of a national, standardized habilitation competition, based on bibliometric indicators, could be a step towards reducing gender bias in academic recruitment.

The competition was launched in 2012 for 184 research fields covered by the Italian Ministry for Universities and Research, thus providing an opportunity to compare the proportions of female applications (and their success rate) across various fields. The assessment of the candidates was based on their CV without an interview, and was centered on bibliometric indicators (at least in STEM (Science, Technology, Engineering and Mathematics) fields) of a restricted number of publications. In addition, the habilitation was carried out for associate and full professors, thus making it possible to compare patterns across two stages of the academic career.

Italy is a country of approximately 61 million inhabitants (2013), with about 70 Universities. In 2001, Italian Universities employed about 15,000 full professors and about 17,000 associate professors [19]. In the same year, the proportion of female professors was about 10\% (23\%) for STEM fields, and about $20 \%(36 \%)$ for SSH (Social Sciences and Humanities) fields (for full and associate professors, respectively) [19]. In 2010, the proportion of female University professors in Italy increased to $20 \%$ and $34 \%$ at the full and associate level, respectively [20]. The gap between STEM and SSH fields was also still present in 2010, with an average proportion of female full professors of $15 \%$ vs. 28\%, respectively [20]. Although there has been some improvement over the last decades in the representation of women in academia, such trend can be subject to reversals, as happened, e.g., between 2002 and 2010 for Italian 
$\mathrm{PhD}$ graduates in computer science, where the proportion of women dropped from $39 \%$ to $22 \%$, thus making it even more difficult to redress the general lack of women in informatics [20].

Due to cultural and social reasons, female participation in the Italian labor force is one of the lowest in Europe [21]. However, there is a wide gap in labor participation between low-educated and highly-educated Italian women [22]. There are also important regional differences, with higher unemployment rates and lower female labor market participation in the South [23]. The Italian academic recruitment system has been blocked and reformed various times over the last decades, with a trend towards ever more precarious conditions for researchers, dwindling resources to replace retiring University professors, and increased migration of (early-career) researchers towards other countries [24]. Recruitment to Italian Universities has traditionally been centralized [25], as confirmed by the national nature of the habilitation process studied here, although individual Universities can then recruit staff from the list of habilitated researchers in an autonomous way.

The aims of this study were to (1) compare the proportion of female vs. male applications across broad STEM and SSH fields (from mathematics, physics, chemistry and biology to medicine, architecture, law and economics) in the Italian University habilitation 2012 competition, and (2) to test whether there were differences in female $v s$. male success rates in the competition. An additional test was performed to study whether differences in female $v s$. male success rates were associated with differences in the number of female members of the evaluating commissions.

\section{Materials and Methods}

\subsection{Data}

Data on the number and gender of applicants for 184 sub-fields of the Italian 2012 habilitation competition were manually obtained in September 2013 from the web. Data on the success of each individual applicant were then retrieved on the same web site in April 2014 (with exception of 3 sub-fields without results at that time). Following the categorization of the Italian ministry for Universities and Research, the remaining 181 sub-fields were grouped into 14 broad fields ((1) mathematics and informatics; (2) physics; (3) chemistry; (4) geology; (5) biology; (6) medicine; (7) agriculture; (8) architecture; (9) engineering; (10) archeology and literature; (11) history and philosophy; (12) law; (13) economics; (14) politics and sociology). The proportion of female applications, the success rate of female applications, and the difference in the success rate between female and male applications were calculated for all fields and sub-fields, both for associate and full professors.

Applicants could be researchers and/or University lecturers, with or without tenure. It is possible that applicants to the habilitation to full professor were already associate professors, but they did not need to be so. The competition was not for professorial positions, but for the habilitation to become so, as success in the procedure gave then the right to apply for professorial positions (over the following 4 years, then extended to 6 years). Applications were possible between July and November 2012.

The evaluating commissions were composed of five senior academic members, of which as a rule one was based in an OSCE (Organization for Security and Cooperation in Europe) country other than Italy. There were no quotas or rules regarding the gender balance of the evaluating commissions. 


\subsection{Statistical Analysis}

Statistical analyses were run in R. The comparison within the 14 main fields (at the full and associate professor levels) of (1) the average number of candidates, (2) the proportion of female vs. male applications, and (3) female and male success rates were performed using a paired $t$-test ( R function $=$ " $t$-test"). The analysis for the 14 main fields (at the full and associate professor levels) of whether the (1) success rates of female applications and (2) difference between female and male success rates were associated with variations in the number of female members of the evaluating commissions was performed using a linear regression (R function = " $\mathrm{lm}$ ").

\section{Results and Discussion}

\subsection{Results}

Overall, there were 59,150 applications, of which 18,082 (31\%) at the full and 41,068 (69\%) at the associate professor level. At the full professor level, about $64 \%$ of the applications were in STEM fields, whereas this proportion was about $60 \%$ at the associate professor level. The number of applications ranged in the various field categories between 400 (geology) and 3298 (medicine) for full professors, and between 831 (geology) and 6689 (medicine) for associate professors (Figure 1a). For all 14 main fields, the number of applications at the associate professor level was significantly higher than at the full professor level (paired $t$-test, $p<0.001$ in all cases, Figure 1a).

The total number of female applications was 21,552 (36\%), of which 5,224 (24\%) at the full and $16,328(76 \%)$ at the associate professor level. The proportion of female applications was lower for full (29\%) compared to associate (39\%) professors. At the level of full professors, the proportion of female applications ranged between 17\% (physics; engineering) and 46\% (archeology and literature) (Figures $1 \mathrm{~b}$ and $2 \mathrm{a}$ ), with an average of $25 \%$ for STEM and $36 \%$ for SSH fields. At the level of associate professors, this proportion ranged between 21\%-23\% (engineering; physics) and 57\% (biology) (Figures $1 \mathrm{~b}$ and $2 \mathrm{~b}$ ), with an average of $37 \%$ for STEM and of $43 \%$ for the SSH fields.

The proportion of female applications was significantly higher $(p<0.01)$ at the associate compared to the full professor level in all main fields, with exception of (1) mathematics and informatics, (2) geology, and (3) politics and sociology, where there were no significant differences (Figure 1b). There was an increase in the proportion of female applications between the full and the associate professor level for $163(89 \%)$ of the subfields. Female applications were the majority in 11 subfields $(6 \%)$ at the full professor level, and in 44 subfields (24\%) at the associate professor level.

Overall, the success rate of applications was on average $42.9 \%$, with a range at the full professor level between $34 \%$ (history and philosophy) and 58\% (agriculture), and at the associate professor level between $35 \%$ (politics and sociology) and 61\% (physics). The success rate of female applications was on the whole $41.2 \%$, i.e., $2.7 \%$ lower than for male applicants. However, this difference was not statistically significant when pooling data from all subfields and at both full and associate professor levels $(n=362, p=0.41)$. 

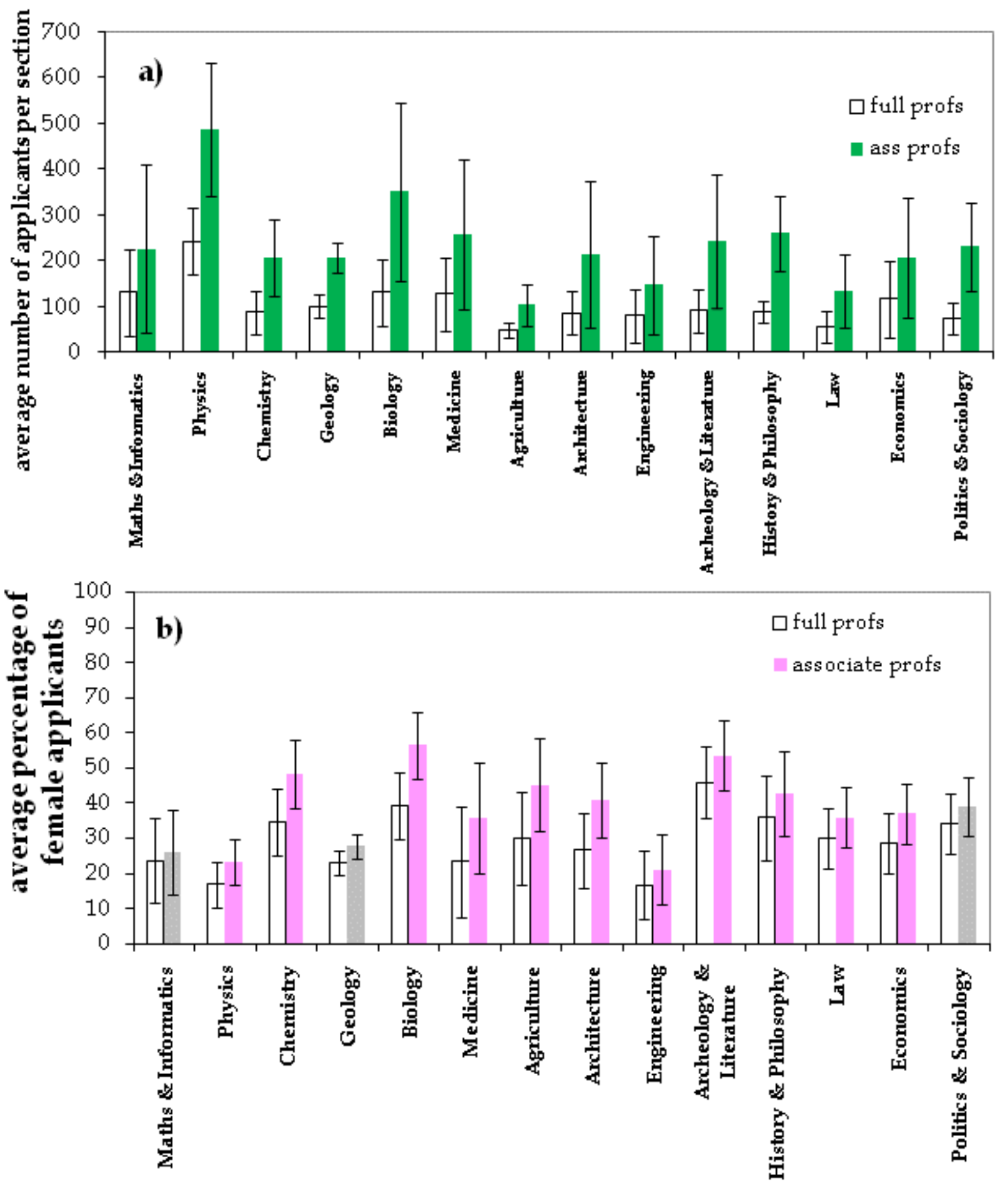

Figure 1. Frequency distribution in the 14 fields of the Italian national habilitation competition (2012) of (a) the average number of applications per sub-field, and (b) the average proportion of female applications (associate and full professor levels). Significant differences (paired $t$-test, all with $p<0.01$ ) are shown in colour. The only non-significant differences are in the panel (b) for mathematics and informatics $(p=0.18)$, geology $(p=0.28)$, and politics and sociology $(p=0.25)$. Error bars show standard deviations. 

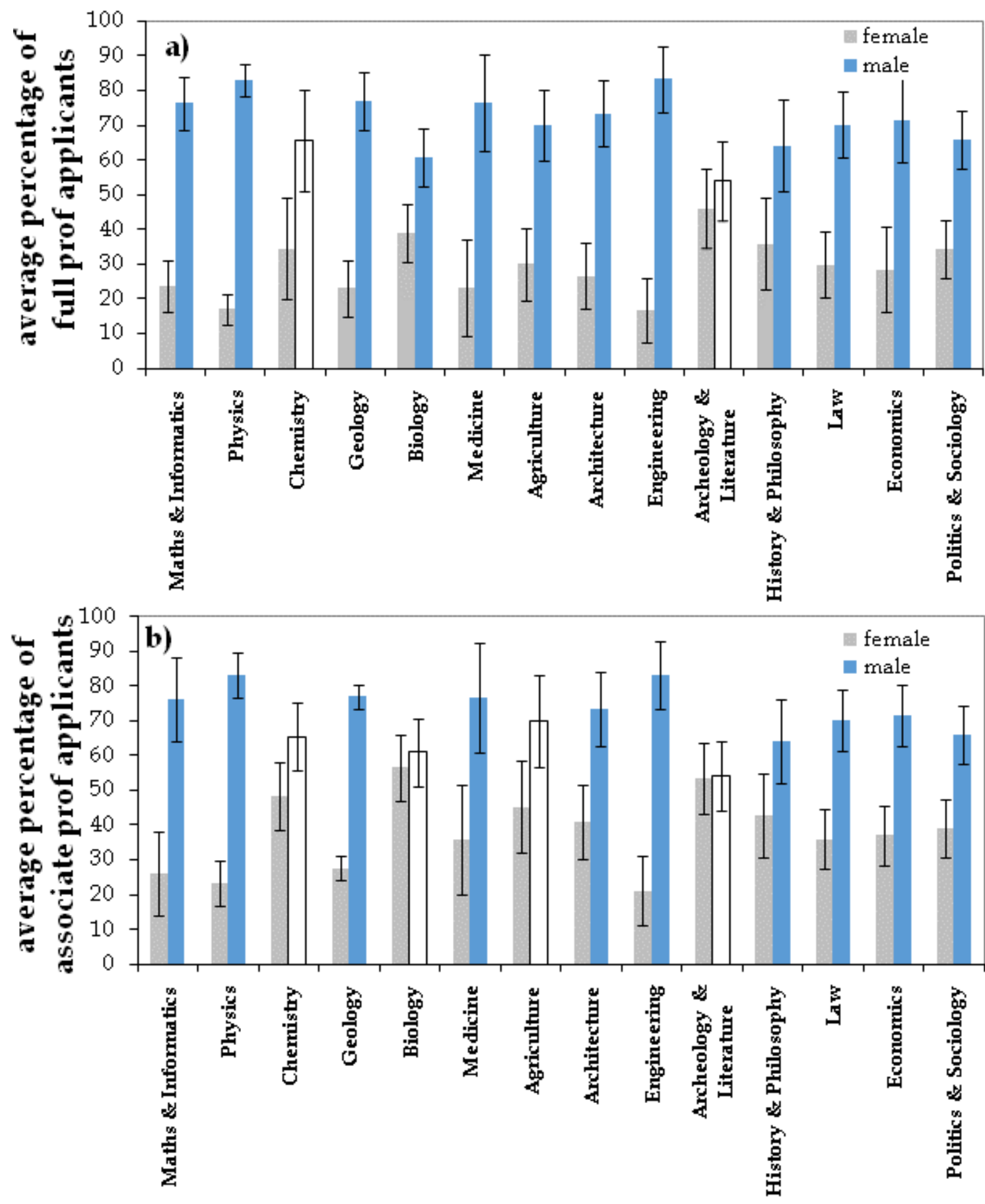

Figure 2. Frequency distribution in the 14 fields of the Italian national habilitation competition (2012) of the average percentage of female $v s$. male applications at the (a) full and (b) associate professor levels. Significant differences (paired $t$-test, all with $p<0.01$, apart from history and philosophy with $p=0.049$ ) are shown in color. The only non-significant differences are in panel (a) for chemistry $(p=0.06)$, and archeology and literature $(p=0.16)$, and in panel (b) for chemistry $(p=0.81)$, biology $(p=0.08)$, agriculture $(p=0.64)$, and archeology and literature $(p=0.14)$. Error bars show standard deviations.

The success rate of female applications ranged between 30\% (geology) and 57\% (chemistry) at the full professor level (Figure 3a), and between 35\% (politics and sociology) and 64\% (physics) at the associate professor level (Figure 3b). Overall, whilst there was no significant difference in the average 
success rate of female (44.1\%) vs. male (43.8\%) applications across subfields at the full professor level ( $n=181, p=0.80)$, the success rate of female applications $(43.3 \%)$ was significantly lower than for male applications $(44.9 \%)$ at the associate professor level $(n=181, p=0.03)$.

In STEM subfields $(n=108)$, the success rate of female applications was on average lower than for male applications $(44.8 \%$ vs. $47.0 \%$ at the full professor level, but without significant differences ( $p=0.25$ ), and $44.6 \%$ vs. $47.5 \%$ at the associate professor level, $p<0.001$ ). The reverse was the case in SSH subfields $(n=73)$, where the success rate of female applications was on average higher than for male applications $(43.1 \%$ vs. $39.2 \%$ at the full professor level $(p=0.052)$, and $41.5 \% v s .41 .0 \%$ at the associate professor level, but without significant differences $(p=0.64))$. However, there were marked variations in female and male success rates across subfields, both for STEM and SSH disciplines.

In the 14 broad fields, the average success rate of female applications was generally not significantly different from the success rate of male applications, because of the high variation between sub-fields, both at the full (Figure 3a) and associate professor level (Figure 3b). There were some exceptions: at the full professor level, female success rates were significantly higher (see Figure 3a legend for $p$ values) than male success rates in (1) history and philosophy and (2) law (Figure 3a). At the associate professor level, female success rates were significantly higher (see Figure $3 b$ legend for $p$ values) than male success rates again in law, whereas male success rates were significantly higher (see Figure $3 \mathrm{~b}$ legend for $p$ values) than female success rates in (1) medicine, (2) engineering, and (3) archeology and literature (Figure $3 b$ ). There were 88 subfields (49\%) at the full professor level and 103 subfields (57\%) at the associate professor level with lower success rates for female compared to male applications.

The average number of female members (out of five) of the evaluating commissions varied between 0 (physics) and 1.8 (archeology and literature). This pattern was the same at the full and associate professor level as the commissions were identical at the two levels for each single subfield. There were only 12 evaluating commissions (7\%) with a majority of female members. There were $74(40 \%)$ evaluating commission without female members. However, given the high variability in female success rates among subfields, there was generally no significant correlation of the number of female members in the evaluating commissions with (1) the success rates of female applications and (2) the differences in success rates of female $v s$. male applications.

There were some exceptions: the success rate of female applications was significantly positively associated with the number of female members of the evaluating commissions in law at both the full ( $n=16$ subfields, $R^{2}=0.41, p=0.004$ ) and associate ( $n=16$ subfields, $R^{2}=0.24, p=0.03$ ) professor level. Moreover, the difference in success rates of female $v s$. male applications was significantly positively associated with the number of female members in the evaluating commissions at the full professor level in (1) biology ( $n=12$ subfields, $\left.R^{2}=0.36, p=0.02\right)$ and (2) law ( $n=16$ subfields, $\left.R^{2}=0.61, p<0.001\right)$, and for associate professors in agriculture $\left(n=14\right.$ subfields, $\left.R^{2}=0.28, p=0.03\right)$.

\subsection{Discussion}

The lack of female senior academics has been documented in recent years in many countries [20,26-30]. For example, at the Laboratory of Molecular Biology in Cambridge, UK, the gender ratio of graduate students was about 1.2 male to 1 female in 2006, yet the male-female ratio of group leaders was over 9 to 1 in the same year [31]. In India, only $15 \%$ of science faculty positions were held by women 
(data reported in 2008) [32]. In France, only about 31\% of the permanent researcher positions at CNRS (the French National Centre for Scientific Research) were held by women in 2004, with negligible improvement since 1946, when the proportion of CNRS women researchers was $30 \%$ (see [33]). In the USA, where women obtained $42 \%$ of doctorates in biology in 1996, the proportion of women was less than $25 \%$ for tenured biology faculty and only $34 \%$ for tenure-track biology faculty in 2006 [34].
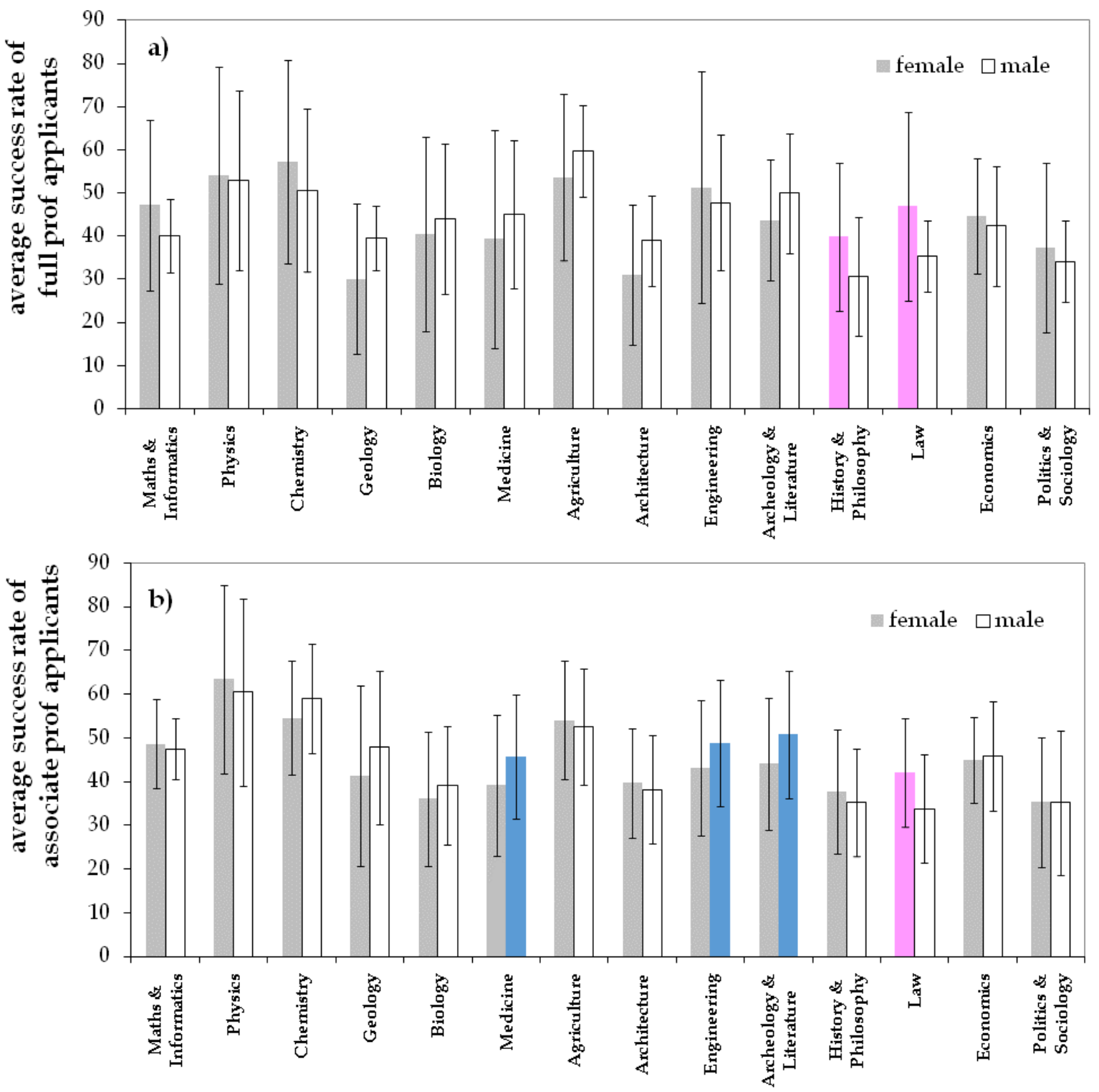

Figure 3. Frequency distribution in the 14 fields of the Italian national habilitation competition (2012) of the average success rates of female vs. male applications for (a) full and (b) associate professors. Non-significant differences (paired $t$-test, all with $p>0.05$ ) are shown in grey. The only significant differences are for panel (a) in history and philosophy $(p=0.02)$ and (marginally) law $(p=0.051)$ (in both cases higher success rate for female candidates), and for panel (b) in medicine ( $p=0.002)$, engineering $(p=0.03)$, archeology and literature $(p<0.001)$ (higher success rates for male candidates) and law $(p=0.003)$ (higher success rate for female candidates). Error bars show standard deviations. 
Also more recent data show the extent and persistence of the problem. In Austria (as of 2011), 58\% of students, $55 \%$ of graduates, and $42 \%$ of doctorates, but only $19 \%$ of lecturers and associate professors and only $17 \%$ of full professors were women [35]. Women currently (data reported in 2015) comprise only $20 \%$ of full-time faculty in academic medicine in the US [36]. At MIT, the current proportion (data reported in 2015) of women faculty in science and engineering departments is the same as the proportion of women in the applicant pools; nevertheless, only $19 \%$ of the science faculty and $17 \%$ of the engineering faculty are women [37]. Some improvements have been documented, for example in academic pharmacy in the US, where, in 2013, women made up $25 \%$ of professors, $46 \%$ of associate professors, and $60 \%$ of assistant professors, with an increase in all sub-disciplines over the previous 10 years [38]. Nonetheless, under-representation persists regarding membership of learned societies. For example, in the UK (data of 2013), only 3\% of the 15,000 members of the Institute of Marine Engineering, Science and Technology were female [39]. Similarly, in April 2014, only 7.2\% of the 41,000 members of the Japanese Surgical Society were female [40]. A review of data on female representation at various academic career stages from European countries is provided by the She Figures Report [20].

In order to solve this problem, it is necessary to monitor the progress of women researchers in academia so as to find out whether selection bias is still occurring [20,41]. At the same time, it is important to quantify the relative importance of various factors contributing to the low proportion of women in academia, so as to better target efforts to fix this challenge [42]. The Italian national University habilitation competition provides an opportunity to study the relative importance of female application rates vs. success rates at two academic stages (associate and full professor level) for a large number of candidates across the whole spectrum of academic fields.

This study documents an increase in the proportion of female applications at the 2012 Italian national habilitation competition $(\sim 36 \%)$ compared to the proportion of female University professors reported for $2010(\sim 27 \%$ ) (see [20]). As a term of comparison, the proportion of female University professors in the UK was about 20\% in 2010-2011 [43]. However, the reported proportion of female applications to the Italian University habilitation is still much lower than the proportion of female researchers in Italy, i.e., the pool of potential candidates, which in 2010 was about $45 \%$ and $51 \%$ for researchers with and without a permanent position, respectively [20]. This confirms that the Italian academia is still not a level playing field for women. We need to avoid gender bias in habilitation applications, otherwise even fewer women will apply for senior academic positions.

There is also evidence for a persisting gap between the proportion of female applications at the associate and full professor levels. This gap is on average about $10 \%$, but varies among fields from $2 \%$ to $17 \%$. A small gap between the proportion of female applications at the associate and full professor level is not actually a good indicator, because it implies that female representation is not improving in the new generation of academics. For example, the smallest gaps are found for mathematics and informatics (2\%), and for engineering (4\%), where the proportions of female applications are very low at both academic levels. However, a large gap is also problematic because it means that the proportion of female applications at the full professor level is still much lower than at the associate professor level, so that more time is still needed for female academics to become better represented at senior academic levels [44]. 
The reported proportions of female applications for the 14 broad categories are averages that can mask some variation at the level of sub-fields [45-47]. For example, whereas the average proportion of female applications at the full professor level in biology was about 38\%, in ecology (a sub-field of biology) this proportion was only $20 \%$. Similarly, whilst the average proportion of female applications at the associate professor level in medicine was about 36\%, in clinical microbiology (a sub-field of medicine) this proportion was $68 \%$, whereas in general surgery the proportion was only $12 \%$. As a term of comparison, in the USA women surgeons were $16 \%$ of faculty at academic medical centers in 2008 [48]. The same point can be made for female (and male) success rates. For example, at the full professor level, whilst the average female success rate was $51 \%$ in engineering, in nuclear engineering female success rates were $67 \%$, but in material science only $20 \%$. Likewise, at the associate professor level, the average female success rate was about $63 \%$ in physics, with a range between $33 \%$ in applied physics and $90 \%$ in theoretical physics of interactions.

The study found evidence for a generally lower success rate of female $v s$. male applications. However, the magnitude of this effect (about $-3 \%$ ) is much smaller than the differences (overall about $-28 \%$ ) in the proportion of female (about 36\%) vs. male (about 64\%) applications, so that it can be concluded that the current relative lack of female Italian researchers habilitated to apply to University positions is mainly due to a lower number of female applications, rather than a lower success rate of female applications. Therefore, efforts to increase the (Italian) proportion of women in academia are likely to be more effective if focusing on the reasons behind the low proportion of female applications, rather than trying to avoid gender bias in the assessment of female applications, given that these are already generally just as successful as male ones, as also reported from France for economists [49].

With a few exceptions, there was generally no significant correlation between the number of female members of the judging commissions and female success rates (or differences between female and male success rates), both at the full and associate professor level, possibly due to the use of quantitative indicators in the assessment of candidates. Interviews might have instead resulted in biased decisions, given the high proportion (40\%) of commissions without female members and previous reports of gender bias in such situations [50-52]. The few observed cases where a higher proportion of male members of the evaluating commissions was associated with (1) lower female success rates, or (2) higher male success rates compared to female success rates, call for mandatory gender balance in higher education assessment commissions. This result is in disagreement with a working paper, which reported a negative effect of the presence of female committee members (not absolute numbers (as in the present study), but relative to the number of female committee members expected from the pool of candidates to that committee) on female success rates, using data from the same habilitation [53]. Given the strong variation in success rates among fields, it is important to base these analyses on comparable data from individual fields [54].

\section{Conclusions}

The progressive loss of female researchers from academia is a waste of resources and talent, which needs redressing [55-60]. It is a good sign that Italian female applications to the 2012 University habilitation are now the majority at the associate professor level for about one quarter of the sub-fields, including popular subjects such as molecular biology, human anatomy and biochemistry. This result 
does not rule out that gender bias might still operate in these fields [61], so that it is important to carry on removing barriers to women careers also in academic fields where female researchers are now the majority of applications to the University habilitation [62-65]. Further research could investigate gender bias in (1) how long researchers stay in the same academic position without career development, and (2) application success rates of researchers participating to the national habilitation competition with or without a tenure track or a permanent position. Even more effort is needed to encourage and support women in choosing and pursuing academic careers in fields such as engineering, informatics and physics, given the still low proportion of female applications at $\mathrm{PhD}$, associate and full professor levels in those disciplines [20,66-68]. Measures that have been suggested include:

- formal and informal mentoring programs [69-71];

- $\quad$ networking and funding opportunities for women during and after career breaks [72-74];

- $\quad$ gender equality awareness workshops and campaigns for University leaders [75-77];

- $\quad$ linking funding to gender equality policies of research institutions [78-80];

- $\quad$ gender-blind faculty search by individual Universities $[48,81]$;

- faculty appointments based on creativity and originality, rather than publication numbers [31];

- $\quad$ onsite childcare facilities at Universities and conferences [56,82,83];

- $\quad$ improving the work-life balance of academic careers [37,83-85]; and

- gender quotas for (1) editorial boards of journals, (2) committees evaluating grant applications, hiring decisions and promotions, (3) academic senior management positions, and (4) invited speakers at conferences[86-90].

These measures are all likely to contribute to increasing the presence of women in academia, particularly if they boost the likelihood that female researchers apply for academic positions in the first place [91]. Nonetheless, in order to increase the representation of women in Italian academia, there is first of all the need to substantially increase resources for Universities, so as to make it possible for them to scale up recruitment of young University professors [92,93]. Gender is one of the priorities of the European Research Area [20,94], but the Italian 2012 habilitation competition confirms that we are still far away from a balanced proportion of female and male academics in most research fields.

\section{Acknowledgments}

Many thanks to M. Luisa Bianco, Anna Cavadini, Trude Hirsch, Ottmar Holdenrieder and the members of "Voice of the Researchers", a group of 25 researchers selected by the European Commission to improve research career conditions by building a bridge between researchers and policy-makers, for information, discussion and support, and to Paola Battilani, Julia Higgins, Christine Maggs, Marie Thursby and anonymous reviewers for helpful comments on a previous draft.

\section{Conflicts of Interest}

The author declares no conflict of interest. 


\section{References}

1. Ceci, S.J.; Williams, W.M. Understanding current causes of women's underrepresentation in science. Proc. Natl. Acad. Sci. USA 2011, 108, 3157-3162.

2. O'Brien, K.R.; Hapgood, K.P. The academic jungle: Ecosystem modelling reveals why women are driven out of research. Oikos 2012, 121, 999-1004.

3. Adamo, S.A. Attrition of women in the biological sciences: Workload, motherhood, and other explanations revisited. BioScience 2013, 63, 43-48.

4. Rees, T. Mainstreaming gender equality in science in the European Union: The ETAN report. Gend. Educ. 2001, 13, 243-260.

5. Neugebauer, K.M. Keeping tabs on the women: Life scientists in Europe. PLoS Biol. 2006, 4, doi:10.1371/journal.pbio.0040097.

6. Stamm, J. Women in science - Why networking matters. European Review 2010, 18, 121-131.

7. Bryson, $\mathrm{C}$. The consequences for women in the academic profession of the widespread use of fixed term contracts. Gend. Work Org. 2004, 11, 187-206.

8. Ioannidou, E.; Rosania, A. Under-representation of women on dental journal editorial boards. PLoS One 2015, 10, doi:10.1371/journal.pone.0116630.s

9. Moss-Racusin, C.A.; Molenda, A.K.; Cramer, C.R. Can evidence impact attitudes? Public reactions to evidence of gender bias in STEM fields. Psychol. Women Quart. 2015, 2015, doi:10.1177/0361684314565777.

10. Ceci, S.J.; Ginther, D.K.; Kahn, S.; Williams, W.M. Women in science: The path to progress. Sci. Am. Mind 2015, 26, 62-69.

11. O'Connor, P. Understanding success: A case study of gendered change in the professoriate. J. High. Educ. Policy Manag. 2014, 36, 212-224.

12. Stroude, A.; Bellier-Teichmann, T.; Cantero, O.; Dasoki, N.; Kaeser, L.; Ronca, M.; Morin, D. Mentoring for women starting a $\mathrm{PhD}$ : A "free zone" into academic identity. Int. J. Mentoring Coaching Educ. 2015, 4, 37-52.

13. Van den Brink, M.; Brouns, M.; Waslander, S. Does excellence have a gender? A national research study on recruitment and selection procedures for professorial appointments in The Netherlands. Empl. Relat. 2006, 28, 523-539.

14. Carvalho, T.; Santiago, R. New challenges for women seeking an academic career: The hiring process in Portuguese higher education institutions. J. High. Educ. Policy Manag. 2010, 32, 239-249.

15. Bagilhole, B.; White, K. Generation and Gender in Academia; Palgrave Macmillan: UK, 2013.

16. Bagilhole, B.; White, K. Gender, Power and Management: A Cross Cultural Analysis of Higher Education; Palgrave Macmillan: UK, 2011.

17. Morley, L. Women and Higher Education Leadership: Absences and Aspirations; Leadership Foundation: London, UK, 2013.

18. Morley, L. Lost leaders: Women in the global academy. High. Educ. Res. Dev. 2014, 33, 114-128.

19. Bianco, M.L. Effetti della riforma dei concorsi universitari su carriere accademiche e dinamiche di genere. Polis 2002, 3, 417-444. (In Italian)

20. She Figures 2012. Gender in Research and Innovation. Available online: http://ec.europa.eu/research/ science-society/document_library/pdf_06/she-figures-2012_en.pdf (accessed on 5 March 2015). 
21. Balleer, A.; Gomez-Salvador, R.; Turunen, J. Labour force participation across Europe: A cohort-based analysis. Empir. Econ. 2014, 46, 1385-1415.

22. Solera, C.; Bettio, F. Women's continuous careers in Italy: The education and public sector divide. Popul. Rev. 2013, 52, doi:10.1353/prv.2013.0007.

23. Guetto, R. Structural and Cultural Determinants of Fertility and Female Labour Market Participation in Italy and Europe. Ph.D. Thesis, University of Trento, Trento, Italy, 2012.

24. Lissoni, F.; Mairesse, J.; Montobbio, F.; Pezzoni, M. Scientific productivity and academic promotion: A study on French and Italian physicists. Ind. Corp. Change 2011, 20, 253-294.

25. Pezzoni, M.; Sterzi, V.; Lissoni, F. Career progress in centralized academic systems: Social capital and institutions in France and Italy. Res. Policy 2012, 41, 704-719.

26. Fraumeni, B.M. Report of the committee on the status of women in the economics profession 2010. Am. Econ. Rev. 2011, 101, 731-736.

27. Larivière, V.; Ni, C.Q.; Gingras, Y.; Cronin, B.; Sugimoto, C.R. Global gender disparities in science. Nature 2013, 504, 211-213.

28. Paul-Hus, A.; Bouvier, R.L.; Ni, C.; Sugimoto, C.R.; Pislyakov, V.; Larivière, V. Forty years of gender disparities in Russian science: A historical bibliometric analysis. Scientometrics 2015, 102, 1541-1553.

29. Cheng, L.-F. Why aren't women sticking with science in Taiwan? Kaohsiung J. Med. Sci. 2010, 26, S28-S34.

30. Fohlmeister, J.; Helling, Ch. Career situation of female astronomers in Germany. Astronomische Nachrichten 2012, 333, 280-286.

31. Lawrence, P.A. Men, women, and ghosts in science. PLoS Biology 2006, 4, doi:10.1371/journal. pbio.0040019

32. Bagla, P. Indian government offers helping hand to women scientists. Science 2008, 319, doi:10.1126/science.319.5869.1470b.

33. De Cheveigné, S. The career paths of women (and men) in French research. Soc. Stud. Sci. 2009, 39, 113-136.

34. Hill, C.; Corbett, C.; St. Rose, A. Why so few? In Women in Science, Technology, Engineering, and Mathematics; American Association of University Women: Washington, DC, USA, 2010.

35. The Difficulties of Gender Equality Governance at Austrian Universities. A Problem of Competing Institutional Logics? Available online: http://genderinacademia.sabanciuniv.edu/sites/ genderinacademia.sabanciuniv.edu/files/birgit_sauer.pdf (accessed on 5 March 2015).

36. Carr, P.L.; Gunn, C.M.; Kaplan, S.A.; Raj, A.; Freund, K.M. Inadequate progress for women in academic medicine: Findings from the national faculty study. J. Women's Health, in press.

37. Hopkins, N. Reflecting on fifty years of progress for women in science. DNA Cell Biol. 2015, 34, 159-161.

38. Draugalis, J.R.; Plaza, C.M.; Taylor, D.A.; Meyer, S.M. The status of women in US academic pharmacy. Am. J. Pharm. Educ. 2014, 78, doi:10.5688/ajpe7810178.

39. Mackenzie, B. The "leaky pipeline": Examining and addressing the loss of women at consecutive career stages in marine engineering, science and technology. In Maritime Women: Global Leadership; Kitada, M., Williams, E., Loloma, L., Eds.; Springer: Berlin, Germany, 2015; pp 69-81. 
40. Tomizawa, Y. Gender gap in medicine: Only one woman councilor in the Japan surgical society. Tohoku J. Exp. Med. 2015, 235, 97-102.

41. Groeneveld, S.; Tijdens, K.; van Kleef, D. Gender differences in academic careers: Evidence for a Dutch university from personnel data 1990-2006. Equal. Divers. Incl. Int. J. 2012, 31, 646-662.

42. Shaw, A.K.; Stanton, D.E. Leaks in the pipeline: Separating demographic inertia from ongoing gender differences in academia. Proc. Royal Soc. 2012, 279, 3736-3741.

43. Howe-Walsh, L.; Turnbull, S. Barriers to women leaders in academia: Tales from science and technology. Stud. High. Educ., in press.

44. Kessel, C. Understanding underrepresentation: Women in mathematics and other fields. Math. Intell. 2014, 36, 10-18.

45. D'Amico, R.; Vermigli, P.; Canetto, S.S. Publication productivity and career advancement by female and male psychology faculty: The case of Italy. J. Divers. High. Educ. 2011, 4, 175-184.

46. Magnavita, N. Is there a gender gap in Italian radiology? A cross-sectional study. Eur. J. Radiol. 2013, 82, 502-507.

47. Baxter, B.K.; Gunde-Cimerman, N.; Oren, A. Salty sisters: The women of halophiles. Front. Microbiol. 2014, 5, doi:10.3389/fmicb.2014.00192.

48. Morton, M.J.; Bristol, M.B.; Atherton, P.H.; Schwab, C.W.; Sonnad, S.S. Improving the recruitment and hiring process for women faculty. J. Am. Coll. Surg. 2008, 206, 1210-1218.

49. Bosquet, C.; Combes, P.-P.; Garcia-Penalosa, C. Gender and Promotions: Evidence from Academic Economists in France; LIEPP Working Paper n 29; Laboratoire interdisciplinaire d'évaluation des politiques publiques: Paris, France, 2014.

50. De Paola, M.; Scoppa, V. Gender Discrimination and Evaluators' Gender: Evidence from the Italian Academy; Working Paper n. 06; Dipartimento di Economia e Statistica, Università della Calabria: Cosenza, Italy, 2011.

51. Moss-Racusin, C.A.; Dovidio, J.F.; Brescoll, V.L.; Graham, M.J.; Handelsman, J. Science faculty's subtle gender biases favor male students. Proc. Natl. Acad. Sci. USA 2012, 109, 16474-16479.

52. Casadevall, A.; Handelsman, J. The presence of female conveners correlates with a higher proportion of female speakers at scientific symposia. mBio 2014, 5, doi:10.1128/mBio.00846-137.

53. Do Gender Quotas Pass the Test? Evidence from Academic Evaluations in Italy. Available online: http://www.lem.sssup.it/WPLem/files/2014-14.pdf (accessed on 5 March 2015).

54. Baccini, A.; Barabesi, L.; Cioni, M.; Pisani, C. Crossing the hurdle: The determinants of individual scientific performance. Scientometrics 2014, 101, 2035-2062.

55. Reuben, E.; Sapienza, P.; Zingales, L. How stereotypes impair women's careers in science. Proc. Natl. Acad. Sci. USA 2014, 111, 4403-4408.

56. McGuire, K.L.; Primack, R.B.; Losos, E.C. Dramatic improvements and persistent challenges for women ecologists. BioScience 2012, 62, 189-196.

57. Danell, R.; Hjerm, M. Career prospects for female university researchers have not improved. Scientometrics 2013, 94, 999-1006.

58. Pautasso, M. Focusing on publication quality would benefit all researchers. Trends Ecol. Evol. 2013, 28, 318-320.

59. Monroe, K.R.; Choi, J.; Howell, E.; Lampros-Monroe, C.; Trejo, C.; Perez, V. Gender equality in the ivory tower, and how best to achieve it. Political Sci. Politics 2014, 47, 418-426. 
60. Penny, M.; Jeffries, R.; Grant, J.; Davies, S.C. Women and academic medicine: A review of the evidence on female representation. J. Royal Soc. Med. 2014, 107, 259-263.

61. Van den Brink, M.; Stobbe, L. The support paradox: Overcoming dilemmas in gender equality programs. Scand. J. Manag. 2014, 30, 163-174.

62. Isbell, L.A.; Young, T.P.; Harcourt, A.H. Stag parties linger: Continued gender bias in a female-rich scientific discipline. PLoS One 2012, 7, doi:10.1371/journal.pone.0049682.

63. Addessi, E.; Borgi, M.; Palagi, E. Is primatology an equal-opportunity discipline? PLoS One 2012, 7, doi:10.1371/journal.pone.0030458.

64. Abramo, G.; D’Angelo, C.A.; Murgia, G. Gender differences in research collaboration. J. Informetr. 2013, 7, 811-822.

65. Heijstra, T.; Bjarnason, T.; Rafnsdóttir, G.L. Predictors of gender inequalities in the rank of full professor. Scand. J. Educ. Res., in press.

66. Cain, C.L.; Leahey, E. Cultural correlates of gender integration in science. Gend. Work Org. 2014, 21, 516-530.

67. Apel, R.; Leicht-Scholten, C.; Wolffram, A. Changing the face of STEM: the example of computer science in Germany. In GIEE 2011: Gender and Interdisciplinary Education for Engineers; Béraud, A., Godfroy, A.-S., Michel, J., Eds.; Springer: Berlin, Germany, 2012; pp 421-437.

68. Curriculare Vorschläge zur. Erhöhung des Frauenanteils in der Informatik. Available online: http://mod.iig.uni-freiburg.de/cms/fileadmin/publikationen/curriculuminf.pdf (accessed on 5 March 2015).

69. Pell, A.N. Fixing the leaky pipeline: women scientists in academia. J. Anim. Sci. 1996, 74, 2843-2848.

70. Karukstis, K.K.; Gourley, B.L.; Wright, L.L.; Rossi, M. Mentoring strategies to recruit and advance women in science and engineering. J. Chem. Educ. 2010, 87, 355-356.

71. Thomas, N.; Bystydzienski, J.; Desai, A. Changing institutional culture through peer mentoring of women STEM faculty. Innov. High. Educ., in press.

72. Bowler, S. Try not to work too hard. A\&G News Views Astron. Geophys. 2010, 51, doi:10.1111/j.1468-4004.2010.51109.x.

73. Mavriplis, C.; Heller, R.; Beil, C.; Dam, K.; Yassinskaya, N.; Shaw, M.; Sorensen, C. Mind the gap: Women in STEM career breaks. J. Technol. Manag. Innov. 2010, 5, 140-151.

74. Perry, K. Daphne Jackson Fellowships offer returners the chance to re-establish a research profile after a career break. Endocr. Abstr. 2013, 31, doi:10.1530/endoabs.31.YE1.5.

75. Greene, J.; Lewis, P.; Richmond, G.; Stockard, J. Addressing gender equity in the physical sciences: Replications of a workshop designed to change the views of department chairs. J. Women Minorities Sci. Eng. 2011, 17, 97-109.

76. Greene, J.; Lewis, P.A.; Richmond, G.L.; Stockard, J. Changing the chairs: Impact of workshop activities in assisting chemistry department chairs in achieving racial and ethnic diversity. J. Chem. Educ. 2011, 88, 721-725.

77. McClelland, S.I.; Holland, K.J. You, me, or her. Leaders' perceptions of responsibility for increasing gender diversity in STEM departments. Psychol. Women Quart., in press.

78. Donald, A.; Harvey, P.H.; McLean, A.R. Athena SWAN awards: Bridging the gender gap in UK science. Nature 2011, 478, doi:10.1038/478036b. 
79. Royal Society of Edinburgh. Tapping All Our Talents, Women in Science, Engineering, Technology and Mathematics; A Strategy for Scotland; Royal Society of Edinburgh: Edinburgh, UK, 2012.

80. Cheung, A. Rewards help institutions focus on gender inequality. New Sci. 2014, 221, 56-57.

81. Jones, C.S.; Urban, M.C. Promise and pitfalls of a gender-blind faculty search. BioScience 2013, 63, 611-612.

82. Lee, C.M.; Reissing, E.D.; Dobson, D. Work-life balance for early career Canadian psychologists in professional programs. Can. Psychol. 2009, 50, 74-82.

83. Siller, H.; Bader, A.; Waldenberger-Steidl, B.; Hochleitner, M. Female and male physicians in academic medicine: Is work-life balance still an issue? In Paths to Career and Success for Women in Science; Thege, B., Popescu-Willigmann, S., Pioch, R., Badri-Höher, S., Eds.; Springer: Berlin, Germany, 2014; pp. 191-206.

84. Machado-Taylor, M.L.; White, K.; Gouveia, O. Job satisfaction of academics: Does gender matter? High. Educ. Policy 2014, 27, 363-384.

85. Bodewits, K.; Gramlich, P. Infrastructure, confidence and network: motherhood as a scientist in Germany. In Paths to Career and Success for Women in Science; Thege, B., Popescu-Willigmann, S., Pioch, R., Badri-Höher, S., Eds.; Springer: Berlin, Germany, 2014; pp. 289-303.

86. Jagsi, R.; Tarbell, N.J.; Henault, L.E.; Chang, Y.; Hylek, E.M. The representation of women on the editorial boards of major medical journals: A 35-year perspective. Arch. Int. Med. 2008, 168, 544-548.

87. Amrein, K.; Langmann, A.; Fahrleitner-Pammer, A.; Pieber, T.R.; Zollner-Schwetz, I. Women underrepresented on editorial boards of 60 major medical journals. Gend. Med. 2011, 8, 378-387.

88. Van den Brink, M. Scouting for talent: Appointment practices of women professors in academic medicine. Soc. Sci. Med. 2011, 72, 2033-2040.

89. Schroeder, J.; Dugdale, H.L.; Radersma, R.; Hinsch, M.; Buehler, D.M.; Saul, J.; Porter, L.; Liker, A.; de Cauwer, I.; Jonhnson, P.J.; et al. Fewer invited talks by women in evolutionary biology symposia. J. Evolut. Biol. 2013, 26, 2063-2069.

90. Pettorelli, N.; Evans, D.M.; Garner, T.W.J.; Katzner, T.; Gompper, M.E.; Altwegg, R.; Branch, T.A.; Johnson, J.A.; Acevedo-Whitehouse, K.; DaVolls, L.; Rantanen, E.; Gordon, I.J. Addressing gender imbalances in Animal Conservation. Anim. Conserv. 2013, 16, 131-133.

91. Leslie, S.-J.; Cimpian, A.; Meyer, M.; Freeland, E. Expectations of brilliance underlie gender distributions across academic disciplines. Science 2015, 347, 262-265.

92. Sessoli, R. Italian research at a turning point: An opportunity that cannot be missed. Angewandte Chemie Int. Edit. 2015, 54, 1374-1375.

93. Docenza Universitaria: Un'intera Generazione è Tagliata Fuori. Available online: http://italians.corriere.it/2015/02/04/31530/ (accessed on 5 March 2015).

94. Sánchez de Madariaga, I. Advancing gender equality in research and innovation in Europe and beyond: COST Network genderSTE. J. Res. Gend. Stud. 2013, 2013, 131-143.

(C) 2015 by the authors; licensee MDPI, Basel, Switzerland. This article is an open access article distributed under the terms and conditions of the Creative Commons Attribution license (http://creativecommons.org/licenses/by/4.0/). 